\title{
Analysis of a Supply-Control Program Under Uncertainty and Imperfect Competition: Chinese Cabbage in Taiwan
}

\author{
Shu-Yu Huang \\ Hsing-Kuo University, Taiwan \\ Richard J. Sexton \\ University of California, Davis, USA \\ Tian Xia \\ Mississippi State University, USA
}

August 2004

Shu-Yu Huang gratefully acknowledges the financial support of the National Science Council, Taiwan. The paper has benefited from the insightful comments of two referees. 


\section{Analysis of a Supply-Control Program Under Uncertainty and Imperfect Competition: Chinese Cabbage in Taiwan}

Marketing firms often make commodity purchase decisions without knowing the future selling price of the finished product. Thus, researchers have often attributed the farmwholesale price spread, after adjusting for marketing costs, as compensation for marketing firms' risk bearing. However, price spreads in excess of marketing costs can also be due to the exercise of market power by the marketing firms. Thus, in settings where both imperfect competition and marketer risk aversion are plausible, a modeling framework must be sufficiently general to accommodate both types of behavior.

This paper develops and estimates such a model in the context of fresh produce marketing. It extends Sexton and Zhang's (SZ, 1996) imperfect-competition produce pricing model to incorporate the role, if any, of marketing firms' risk behavior in price determination, and develops the implications for analysis of supply-control programs for perishable commodities.

The model is able to separate the component of the price spread attributable to market power from that earned as compensation for risk bearing. Thus, the model is able to analyze both theoretically and empirically the relative importance of market power and risk premiums in farm price determination and also the market power and risk aversion effects of policy interventions such as supply control. Failure to adopt a modeling approach that allows price spreads to consist of cost, risk, and market-power components will cause effects of the omitted component(s) to be attributed erroneously to the components that are included. 
The model is applied to the production and marketing of Chinese cabbage in Taiwan and specifically to the analysis of supply-control programs implemented in this industry by the Taiwanese government. The empirical results for this industry provide little support for the hypothesis that marketing firms exhibit risk averse behavior. However, the results do show that marketing firms exercise considerable oligopsony power in procurement of the product from farmers, and that this power is in turn influenced by the quantity supplied in each market period.

We also show that the extent of wholesalers' exercise of market power is variable and directly related to the level of production, which provides an additional, heretofore unexplored, impetus for supply controls intended to raise producer incomes. However, supply controls intended to increase the farm price are also rendered less effective by imperfect competition because marketing firms capture part of the benefits from supply reduction.

\section{Related Research}

The use of supply controls in Taiwan as a price-stabilizing program and concerns about marketing firms' possible market power both stem from great fluctuations in vegetable production and prices. Analysts, including Hsu (1975, 1985), Lee (1989), Hsueh and Chang (1990), and Huang and Huang (1994), have tried to infer marketing firms' behavior from the analysis of price spreads. A consensus view is that high marketing costs, resulting from a complex vertical market structure and long series of oft-repeated services, are a cause of high price spreads. However, the contribution of market power and/or marketing firm risk aversion to high price spreads is unclear and a subject of debate [Hsueh and Chang (1990) and Huang and Huang (1994)]. 
Various authors including Taylor and Kilmer (1988), Huang and Sexton (1996), SZ (1996), Richards and Patterson (2003), and Sexton, Zhang, and Chalfant (2003) have adopted methods of the new empirical industrial organization to study pricing and competition for perishable crops. On balance these studies have confirmed the significant role of market structure and conduct in the formation of price spreads for perishable commodities. For example, SZ found a strong positive relationship between the iceberg lettuce farm-retail price spread and quantity supplied in any market period. These empirical results supported the hypothesis that relatively low supplies diminish buyers' market power, enabling producers to capture a larger proportion of the raw product value.

In contrast, other authors including Brorsen et al. (1985), Brorsen, Chavas, and Grant (1987), Aradhyula and Holt (1989), and Holt (1993) have assumed perfect competition and focused on firms' risk behavior and its effect on the price spread. They found that the more uncertain the firms are about the future selling price, the higher the price spread is, and that a risk premium can constitute a significant proportion of the price spread.

Schroeter and Azzam (SA, 1991) in a study of processor behavior in the US pork industry were the first to develop a model that allows both imperfect competition and risk aversion and to decompose the price spread into components due to marketing costs, imperfect competition, and risk aversion. Azzam (2003) applied the SA framework recently to analyze the impact on market performance of the U.S. Livestock Mandatory Reporting Act of 1999. This study extends SA's work to incorporate the unique characteristics of perishable commodity markets, and develop the implications of the analysis for commodity supply-control programs. 


\section{Conceptual Framework}

We consider a situation where a fixed number of identical marketing firms (e.g., food manufacturers, wholesalers, or handlers) each procure a volume of raw agricultural product, $\mathrm{r}$, from farmers, perform various handling, processing, and marketing functions, and sell a finished product, q, downstream, e.g., to grocery retailers. The selling price, P, for the finished product is unknown at the time that purchase decisions are made, meaning that these decisions are made in situations of risk and uncertainty, as several authors have noted. To simplify the analysis, we assume fixed proportions in converting raw product $r$ into finished product $q$, in which case through choice of measurement units, we can set $r=q$.

The market inverse supply function for the raw product is denoted as $\mathrm{W}(\mathrm{Q}, \mathbf{Y})$, where $\mathrm{W}$ is the farm price, $\mathrm{Q}$ is the market-wide supply of the raw product, and $\mathbf{Y}$ denotes supply shifters. A representative marketing firm's cost function for performing marketing services is denoted as $\mathrm{C}(\mathrm{q}, \mathbf{V})$, where $\mathbf{V}$ is the vector of prices of inputs used in performing the marketing functions. ${ }^{1}$ We attain considerable simplification by assuming constant returns to scale in marketing, so that $\mathrm{C}(\mathrm{q}, \mathbf{V})=\mathrm{c}(\mathbf{V}) \mathrm{q}$, where $\mathrm{c}(\mathbf{V})$ denotes per unit marketing costs. ${ }^{2}$

The market structure we consider is one where the marketing firms are price takers in the market for the finished product, but the firms may exercise oligopsony power in the procurement of the raw farm product. This situation is typical of many agricultural markets [e.g., see Rogers and Sexton (1994) and Richards, Patterson, and

\footnotetext{
${ }^{1}$ Costs of performing marketing services are separable from raw product costs due to the fixed proportions assumption - see Brorsen et al. (1985) for more details.

${ }^{2}$ For compactness of notation, we often omit reference to the "shift" variables $\mathbf{Y}$ and $\mathbf{V}$.
} 
Acharya (2001)] because the raw product market is often smaller in geographic scope than the market for the processed product, and, thus, competition will often be relatively greater in the market for the processed product. Furthermore, relative to farmers, downstream firms such as retailers are ordinarily in a much stronger position to countervail attempts by marketing firms to exercise oligopoly power. ${ }^{3}$

Farm price, $\mathrm{W}$, is known at the time the purchase decision is made, and we also assume that wholesalers have secured at fixed prices the necessary inputs to process and market the raw product, making $\mathrm{c}$ also nonrandom. Output price, $\mathrm{P}$, however, is a random variable, with mean $\mathrm{E}[\mathrm{P}]$ and variance $\sigma_{\mathrm{P}}^{2}$. Let $\mathrm{v}_{\mathrm{d}}\left(0, \sigma_{\mathrm{P}}^{2}\right)$ represent the random component of output price. Profit to a representative marketing firm can then be expressed as

$$
\text { (1) } \begin{aligned}
\pi & =P q-W(Q) q-c q \\
& =[E(P)+v] q-W(Q) q-c q \\
& =[E(P)-W(Q)-c] q+v q .
\end{aligned}
$$

Profit is also a random variable with mean $\mu_{\pi}=[\mathrm{E}[\mathrm{P}]-\mathrm{W}(\mathrm{Q})-\mathrm{c}] \mathrm{q}$ and variance $\sigma_{\pi}^{2}=\sigma_{\mathrm{p}}^{2} \mathrm{q}^{2}$. By defining $\varepsilon=\mathrm{v} / \sigma_{\mathrm{p}} \mathrm{d}(0,1)$, we can express profit in a normalized form as

$$
\pi=\mu_{\pi}+\sigma_{\pi} \varepsilon .
$$

In this model, the only source of risk is the output price, and this random variable linearly affects profits of marketing firms. The model setting thus satisfies the Sinn-Meyer location and scale parameter condition [Bar-Shira and Finkelshtain (1999)], meaning that any ranking of alternatives from a expected utility formulation can also be achieved from

\footnotetext{
${ }^{3}$ The conceptual model is extended easily to accommodate the exercise of oligopoly power by marketing firms, as we demonstrate in an expanded version of this paper, which is available upon request.
} 
a utility expression based only on the means and standard deviations of the alternatives [Sinn (1983) and Meyer (1987)]. ${ }^{4}$

From theorem 1 of Bar-Shira and Finkelshtain (1999), the risk preferences of marketing firms are representable in this setting by a utility function, $U\left(\mu_{\pi}, \sigma_{\pi}\right)$, which is increasing in $\mu_{\pi}$ and decreasing in $\sigma_{\pi}$ under certain conditions. A representative marketing firm's optimization problem can thus be expressed as

$$
\max \{\mathrm{q}\} \quad \mathrm{U}\left(\mu_{\pi}, \sigma_{\pi}\right) .
$$

The first-order condition for (3) can be expressed in elasticity form as

$$
\begin{aligned}
& \frac{\partial \mathrm{U}(\cdot)}{\partial \sigma_{\pi}} \sigma_{\mathrm{P}}+\frac{\partial \mathrm{U}(\cdot)}{\partial \mu_{\pi}}\{\mathrm{E}[\mathrm{P}]-\mathrm{W}(1+\theta / \eta)-\mathrm{c}\}=0, \\
& \text { or }
\end{aligned}
$$

$$
\mathrm{E}[\mathrm{P}]-\mathrm{W}(1+\theta / \eta)-\mathrm{c}=*
$$

where

$*=\left(\frac{-\partial \mathrm{U}(\cdot)}{\partial \sigma_{\pi}} / \frac{\partial \mathrm{U}(\cdot)}{\partial \mu_{\pi}}\right) \sigma_{\mathrm{P}}=\mathrm{S}\left(\sigma_{\pi}, \mu_{\pi}\right) \sigma_{\mathrm{P}}$,

and $\left(\frac{-\partial \mathrm{U}(\cdot)}{\partial \sigma_{\pi}} / \frac{\partial \mathrm{U}(\cdot)}{\partial \mu_{\pi}}\right)=\mathrm{S}\left(\sigma_{\pi}, \mu_{\pi}\right)$ is the slope of the marketer's indifference curve on the $\left(\sigma_{\pi}, \mu_{\pi}\right)$ plane. Given that $\partial \mathrm{U} / \partial \sigma_{\pi}<0$ under risk aversion and $\partial \mathrm{U} / \partial \mu_{\pi}>0$ due to nonsatiation, $\mathrm{S}(\cdot)>0$ indicates marketing firm risk aversion [Meyer (1987)]. ${ }^{5}$

\footnotetext{
${ }^{4} \mathrm{We}$ are grateful to a referee for suggesting that we represent risk preferences in this setting with a meanstandard-deviation (MSD) utility model instead of an expected utility (EU) model. Given the basic consistency between the two approaches, the various authors have argued that the MSD approach is preferable because it (i) imposes fewer restrictions on preference representations and random variable distributions and (ii) makes more tractable the analyses of comparative statics of risk preference and decision making. Further, Bar-Shira and Finkelshtain (1999) and Ormiston and Quiggin (1993) have noted that MSD utility model can account for some violations of EU theory, including paradoxical behaviors, and, therefore, is compatible with general rational decision-making.
} 
In (4') $\theta=(\partial \mathrm{Q} / \partial \mathrm{q})(\mathrm{q} / \mathrm{Q})$ is the marketing firm's conjectural elasticity for the farm market evaluated at the firm's optimum, and $\eta=(\partial \mathrm{Q} / \partial \mathrm{W})(\mathrm{W} / \mathrm{Q})$ is the market price elasticity of supply of the farm product, also evaluated at the firm's optimum. The conjectural elasticity $\theta$ measures the marketing firm's competitive behavior in procurement of the farm product. It ranges in the unit interval, with a value of zero indicating perfect competition, a value of one representing monopsony, and values in the open interval $(0,1)$ representing various degrees of oligopsony power. The term $\theta / \eta$ measures the relative markdown of the farm price from the competitive level, $\mathrm{P}-\mathrm{c}-$ $\mathrm{S} \sigma_{\mathrm{P}}$, and, hence, the term $\mathrm{m}=(1+\theta / \eta)$ in $\left(4^{\prime}\right)$ is a measure of firms' monopsony power, with $\mathrm{m}=1$ denoting perfect competition and $\mathrm{m}>1$ implying imperfect competition. Solving (4') in terms of W obtains

$$
\mathrm{W}=\tilde{\mathrm{m}}\left[\mathrm{E}[\mathrm{P}]-\mathrm{c}-\mathrm{S} \sigma_{\mathrm{p}}\right]
$$

where $\tilde{\mathrm{m}}=\mathrm{m}^{-1}=(1+\theta / \eta)^{-1} \leq 1$ represents the proportion of the competitive farm price that producers receive under buyer oligopsony power.

From (5) the farm price in each period is determined by the expected wholesale market price, $\mathrm{E}[\mathrm{P}]$, per-unit marking costs, $\mathrm{c}$, degree of market power, $\tilde{\mathrm{m}}$, and marginal risk premium, $\mathrm{S} \sigma_{\mathrm{P}}$, as determined by the degree of risk aversion measured by the

\footnotetext{
${ }^{5}$ See Meyer (1987) and Leathers and Quiggin (1991) for further characterization of risk preferences, such as constant absolute risk aversion (CARA) or decreasing absolute risk aversion (DARA) in terms of the sign of the derivative $\partial \mathrm{S} / \partial \mu_{\pi}$. Our estimation strategy is to treat $\mathrm{S}$ as a constant parameter. This strategy is consistent with our overall objective of testing whether the marketing firms exhibit risk-averse behavior, and decomposing margin behavior into components due to marketing costs, risk behavior, and market power. Furthermore, our application to weekly procurement of Chinese cabbage in Taiwan enables us to observe marketers in only a relatively narrow range of their wealth distributions, making it difficult to obtain a reliable estimate of $\partial \mathrm{S} / \partial \mu_{\pi}$.
} 
magnitude of $S$ and the variability, $\sigma_{P}$, of the output price. Equation (5) reduces to perfect competition, risk neutrality, or certainty as special cases:

- $\quad$ perfect competition and risk neutrality: $\tilde{\mathrm{m}}=1, \mathrm{~S}=0 \Rightarrow \mathrm{W}=\mathrm{E}[\mathrm{P}]-\mathrm{c}$,

- certainty and imperfect competition: $\sigma_{\mathrm{P}}=0, \tilde{\mathrm{m}}<1 \Rightarrow \mathrm{W}=\tilde{\mathrm{m}}(\mathrm{E}[\mathrm{P}]-\mathrm{c})$,

- market power and risk neutrality: $\tilde{\mathrm{m}}<1, \mathrm{~S}=0 \Rightarrow \mathrm{W}=\tilde{\mathrm{m}}(\mathrm{E}[\mathrm{P}]-\mathrm{c})$,

- $\quad$ perfect competition and risk aversion: $\tilde{\mathrm{m}}=1, \mathrm{~S}>0 \Rightarrow \mathrm{W}=\mathrm{E}[\mathrm{P}]-\mathrm{c}-\mathrm{S} \sigma_{\mathrm{P}}$.

The consequences of neglecting either market power or risk aversion can be determined by comparing the farm price expression under each simplifying scenario with the general expression in (5). For example, assuming price certainty or risk neutrality, as in the second and third cases, when actually the price is uncertain and firms are risk averse, will cause portions of the price spread to be attributed erroneously to market power and/or marketing costs.

Given the assumption of homogeneous marketing firms, equation (5) represents a general expression for short-run farm-price determination when the marketing firms may have both oligopsony power and risk aversion. Combining (5) with equations for (i) expected wholesale price, (ii) marketing firm per-unit costs, and (iii) raw product supply results in an estimable equilibrium model of industry behavior, provided appropriate identification restrictions are met. ${ }^{6}$

\footnotetext{
${ }^{6}$ For purposes of estimation, an analyst would normally work with the derivative form of (5). Assuming that only market-level data are available, if we substitute $\tilde{\mathrm{m}}=(1+\theta / \eta)^{-1}$ and $\eta=(\partial \mathrm{Q} / \partial \mathrm{W})(\mathrm{W} / \mathrm{Q})$ into (5), it can be written as $\mathrm{W}=\mathrm{E}[\mathrm{P}]-\mathrm{c}(\mathbf{V})-\mathrm{S} \sigma_{\mathrm{P}}-\theta(\partial \mathrm{W} / \partial \mathrm{Q}) \mathrm{Q}$, where $\theta \in[0,1]$. In the most basic formulation, this expression plus the farm product supply function, $\mathrm{W}(\mathrm{Q}, \mathbf{Y})$, comprise the empirical model, and 2 is identified by rotation of the slope of the supply function [e.g., Muth and Wohlgenant (1999)] or by restrictions on the functional form of the expression in (5). Q is endogenous in this formulation, but instruments, $\mathbf{V}$, for $\mathrm{Q}$ are normally available through the cost function. Even if perfect competition for the finished product is assumed, output price may depend upon Q, e.g., $\mathrm{P}(\mathrm{Q}, \mathbf{X})$, but this fact does not unduly complicate estimation, as long as instruments for Q are available. See Schroeter and Azzam (1991) and Sexton and Lavoie (2001) for a more extended discussion on identification issues.
} 


\section{Application to a Perishable Commodity}

This section adapts the model framework from the preceding section to the analysis of price effects of market power and risk aversion for perishable produce commodities and to the impact of these factors on supply-control programs. In this context a modified version of the general framework is appropriate. Short-run supply of produce commodities is inelastic for all prices in excess of per-unit harvest costs, $\mathrm{c}_{\mathrm{H}}$ [SZ, (1996)]. The planting decisions which determine the available supply are made months in advance of price determination, and, hence, the potential supply is unaffected by prices above the per-unit harvest costs. Further, perishable crops cannot be stored across market periods. Thus, all available production will be harvested and brought to market for any price, $\mathrm{W} \geq \mathrm{c}_{\mathrm{H}}$.

This facet of production for a perishable commodity must be incorporated into the model of supply. To do so define $\Sigma(\mathrm{Q})=\mathrm{E}[\mathrm{P}(\mathrm{Q})]-\mathrm{c}-\mathrm{S} \sigma_{\mathrm{P}}-\mathrm{c}_{\mathrm{H}}$ as the per-unit market surplus available for distribution between producers and marketers, given potential harvest $\mathrm{Q}$. Also define $\mathrm{Q}=\mathrm{Q}_{\mathrm{H}}$ as the harvest volume of sufficient magnitude that $\Sigma(\mathrm{Q})=$ 0 , i.e., at harvest $\mathrm{Q}_{\mathrm{H}}$ the wholesale market price less per-unit marketing costs and compensation for risk bearing is just sufficient to cover producers' marginal costs of harvesting the commodity. No volumes in excess of $\mathrm{Q}_{\mathrm{H}}$ will be harvested under any form of competition. As described in SZ (1996), farm price is then determined under either of two alternative regimes, depending upon the magnitude of the potential harvest:

(6a) $\mathrm{W}=\mathrm{c}_{\mathrm{H}}$ for all $\mathrm{Q} \geq \mathrm{Q}_{\mathrm{H}}$

(6b) $\mathrm{W}=\mathrm{c}_{\mathrm{H}}+\hat{\mathrm{m}} \Sigma(\mathrm{Q})=\mathrm{c}_{\mathrm{H}}+\hat{\mathrm{m}}\left\{\mathrm{E}[\mathrm{P}(\mathrm{Q})]-\mathrm{c}-\mathrm{S}_{\mathrm{P}}-\mathrm{c}_{\mathrm{H}}\right\}$ for all $\mathrm{Q}<\mathrm{Q}_{\mathrm{H}}$. 
Equations (6a) and (6b) are the perishable commodity analog of (5). They differ from the more general specification by (a) allowing pricing to be determined by per-unit harvest costs for sufficiently large harvests and (b) by modifying the market surplus term E[P]-c$S \sigma_{\mathrm{P}}$ in (5) to include per-unit harvest costs. ${ }^{7}$ In this formulation the competition parameter, $\hat{\mathrm{m}}$, has a modified interpretation relative to the competition parameter, $\tilde{\mathrm{m}}$, in the general model. $\hat{\mathrm{m}}$ is defined over the interval $[0,1]$, where $\hat{\mathrm{m}}=0$ implies that marketing firms capture the entire expected net surplus, $\Sigma(\mathrm{Q})$, available in the market, and producers are relegated to recovering only their per-unit harvest costs, and $\hat{\mathrm{m}}=1$ denotes perfect competition, i.e., producers, as owners of the asset in fixed supply, capture the entire surplus.

Oligopsony power does not affect production of the farm commodity in the short run; it only affects the distribution of the expected market surplus between producers and marketers. From (6a) and (6b), the farm price change due to a marginal quantity reduction from a supply-control program is

$$
\begin{aligned}
& \partial \mathrm{W} / \partial \mathrm{Q}=0 \quad \text { for } \mathrm{Q} \geq \mathrm{Q}_{\mathrm{H}} \\
& \partial \mathrm{W} / \partial \mathrm{Q}=\hat{\mathrm{m}}\{\partial \mathrm{E}[\mathrm{P}] / \partial \mathrm{Q}\}+(\partial \hat{\mathrm{m}} / \partial \mathrm{Q})\left\{\mathrm{E}[\mathrm{P}]-\mathrm{c}-\mathrm{S} \sigma_{\mathrm{P}}-\mathrm{c}_{\mathrm{H}}\right\} \text { for } \mathrm{Q}<\mathrm{Q}_{\mathrm{H}},
\end{aligned}
$$

where $\partial \mathrm{E}[\mathrm{P}] / \partial \mathrm{Q}<0$ is the slope of the expected inverse market demand for the product at wholesale. From (7a) and (7b), supply-control programs that operate for the range of

\footnotetext{
${ }^{7}$ It could be argued that a harvest-cost pricing constraint should be added to the general pricing model in (5) because, even for commodities in elastic short-run supply, no product will be supplied if price does not at least equal the per-unit harvest costs. A key distinction, as the work of SZ demonstrated and as was confirmed in subsequent work by Sexton, Zhang, and Chalfant (2003), is that the harvest-cost pricing constraint binds in a significant percentage of the harvest periods for a perishable commodity - an estimated $30 \%$ of the time in the SZ study - so that the constraint is an essential element of the pricing model for a perishable produce commodity. A second distinction is storability. Harvest-period prices below per-unit harvest costs may still induce harvest, if producers believe that price in subsequent periods will rise by enough to remunerate both harvest and storage costs.
} 
potential output where $\mathrm{Q} \geq \mathrm{Q}_{\mathrm{H}}$ are ineffective because they support crop removal that would occur in any event due to normal market forces.

Focusing on the case when $\mathrm{Q}<\mathrm{Q}_{\mathrm{H}}$, supply control involves two distinct effects on the farm price. Given that $\hat{\mathrm{m}}<1$ under marketing firm oligopsony power, farm price is less responsive to a given amount of supply control than under perfect competition, as expressed by the first term on the right-hand side of (7b). Supply control's effectiveness as a mechanism to raise farm prices is vitiated, because the marketing firms capture part of the price increase generated by supply control. However, the second term in the expression reflects the possible increase in the farm share as quantity supplied is reduced. Under the SZ (1996) hypothesis, $\partial \hat{\mathrm{m}} / \partial \mathrm{Q}<0$, i.e., large harvests reduce producers' relative power because buyers can threaten credibly to procure the product from alternative sources, and, given that the product is highly perishable, producers have little ability to withstand buyer pressure for price concessions in the presence of large harvests.

The overall effectiveness of supply control in raising producer prices under oligopsony vs. perfect competition, thus, hinges upon the relative strength of the two offsetting effects. Oligopsony buyers will always capture part of the price increase generated by supply control. Moreover, under the SZ hypothesis $\hat{m}$ is relatively low in periods of oversupply, when supply controls are most likely to be implemented. Thus, imperfectly competitive marketers may often capture a large share of the benefits of supply-control programs. However, supply control in the presence of oligopsony may also enhance producers' relative power in the marketplace, giving them a bigger share of the "pie" that is available. 


\section{Empirical Specification}

Chinese cabbage is planted year round in Taiwan. However, the Taiwanese supplycontrol program that was initiated in the $1995-96$ crop year targets winter crops only. ${ }^{8}$ The winter harvests start in mid-October and end in mid-March. The government does not announce a target price for fear of stimulating overproduction by farmers, but in practice, the government plans to plow under surplus commodity whenever the farm price falls below the estimated nonharvest cost of production for three consecutive weeks.

The program requires that participating farmers report the volume of their planting and anticipated harvest date of their crops to township farmers' associations or cooperatives. The Council of Agriculture, Taiwan decides the total hectares to remove for each market period, and then allocates the total among the counties based on their participation levels. The county government assigns a crop removal allotment to each township. Those participating farmers who are willing to plow under their crops receive a subsidy.

Despite the reporting requirements, lack of good information on farmers' planting decisions has caused the length of each episode of crop removal to be somewhat arbitrary, ranging from one to four weeks, as indicated in table 1. In particular, removal of crops during 1997-98 occurred in times of relatively low supply and high prices, while in 1995-96, 1996-97, 1998-99, and 2000-01 crop removal was terminated before the market recovered from sluggish, below-cost prices.

\footnotetext{
${ }^{8}$ The supply control program was initiated by the Taiwanese government in 1995 in response to concerns about sluggish markets for produce commodities. In addition to Chinese cabbage, the program applies to common cabbage and cauliflower.
} 
Harvest of Chinese cabbage is usually done on a custom basis. The process consists of workers cutting and trimming the produce in the fields. After trimming, they box and load the commodity to trucks either in the fields or inside packing facilities located at the farms. Based on information obtained from the farmers' association in the major producing region, per-unit harvest cost during the 1996-2002 period was relatively constant at about NT $\$ 60$, consisting of labor cost of NT $\$ 15$, carton cost of NT $\$ 18$, and shipping costs of NT $\$ 27 .^{9}$ Thus, as table 1 illustrates, the supply-control program has succeeded in raising the farm price above the immutable floor (NT\$60) set by the level of per-unit harvest costs.

Equations (6a) and (6b) provide the basis for estimation. However, we must develop functional specifications for the expected wholesale price, $\mathrm{E}[\mathrm{P}]$, the standard deviation of $\mathrm{P}, \sigma_{\mathrm{P}}$, and wholesalers' marginal marketing costs, c. Following SZ (1996), we adopted linear specifications, and, following Schroeter and Azzam (1991) and Holt (1993), generated the time-varying standard deviation using a generalized autoregressive conditional heteroskedasticity $\operatorname{GARCH}(1,1)$ process:

$$
\begin{aligned}
& P_{t}=B_{0}+B_{1} Q_{t}+B_{2} P_{t-1}+B_{3} P_{t-2}+B_{4} S 1_{t}+B_{5} S_{2}+B_{6} T_{t}+:_{t} \\
& \sigma_{P, t}^{2}=\operatorname{var}\left(P_{t}\right)=Z_{t}=\beta_{0}+\beta_{1} \mu_{t-1}^{2}+\beta_{2} Z_{t-1},
\end{aligned}
$$

In (8) S1 and S2 respectively are indicator variables to identify the week of Chinese New Year (a period of high demand) and the week following Chinese New Year (a period of low demand), $\mathrm{T}$ is a time trend indicating the order of the harvest week within each crop season, and the error term $:_{t}$ is assumed to be independently distributed with conditional

\footnotetext{
${ }^{9}$ Nonharvest costs for seedlings, fertilizer, pesticides, other materials, labor, energy, and machine custom land preparation are estimated to have been NT $\$ 90$ per standardized case $(20 \mathrm{~kg}$. retail weight) for the
} 
mean zero and conditional variance $\mathrm{Z}_{\mathrm{t}}{ }^{10}$ The lagged variables, $\mathrm{P}_{\mathrm{t}-1}$, and $\mathrm{P}_{\mathrm{t}-2}$ allow for dynamics in the adjustment of prices.

Wholesaler marginal cost is specified as a simple function of the labor wage VL:

$$
\mathrm{c}\left(\mathrm{VL}_{\mathrm{t}}\right)=\mathrm{A}_{0}+\mathrm{A}_{1} \mathrm{VL}_{\mathrm{t}}
$$

Labor is the principal variable input in the marketing of produce. The intercept term, $\mathrm{A}_{0}$, accounts for other variable inputs whose prices were constant over the short sample period. Many other inputs are fixed in this short-run setting and, thus, play no role in price determination. For example, wholesalers utilize various services provided collectively by the central market where the produce is bought and sold. Any costs borne by an individual firm for these collective services are fixed.

$E\left[P_{t}\right]$ is obtained simply as the expected value, $\hat{P}_{t}$, of (8). However, an issue arises as to whether marketing firms know the harvest $Q$ at the time they make their purchase decisions or whether $\mathrm{Q}$ is a stochastic exogenous variable, which must be forecast by the wholesalers. In the former case,

$$
\mathrm{E}\left[\mathrm{P}_{\mathrm{t}}\right]=\mathrm{B}_{0}+\mathrm{B}_{1} \mathrm{Q}_{\mathrm{t}}+\mathrm{B}_{2} \mathrm{P}_{\mathrm{t}-1}+\mathrm{B}_{3} \mathrm{P}_{\mathrm{t}-2}+\mathrm{B}_{4} \mathrm{~S} 1_{\mathrm{t}}+\mathrm{B}_{5} \mathrm{~S} 2_{\mathrm{t}}+\mathrm{B}_{6} \mathrm{~T}_{\mathrm{t}}
$$

whereas in the latter case

$$
\mathrm{E}\left[\mathrm{P}_{\mathrm{t}}\right]=\mathrm{B}_{0}+\mathrm{B}_{1} \mathrm{E}\left[\mathrm{Q}_{\mathrm{t}}\right]+\mathrm{B}_{2} \mathrm{P}_{\mathrm{t}-1}+\mathrm{B}_{3} \mathrm{P}_{\mathrm{t}-2}+\mathrm{B}_{4} \mathrm{~S}_{\mathrm{t}}+\mathrm{B}_{5} \mathrm{~S}_{\mathrm{t}}+\mathrm{B}_{6} \mathrm{~T}_{\mathrm{t}}
$$

and an equation for forecasting $\mathrm{Q}_{\mathrm{t}}$ must also be specified. Because there was little conceptual basis on which to choose between (11) and (11'), the model was estimated

1998/99 and 1999/2000 crop years (Council of Agriculture, Taiwan). Thus, total production costs for the sample period were about NT $\$ 150$, excluding land costs.

${ }^{10}$ The length of lags for $P_{t}$ and $Z_{t}$ was determined by tests of significance of parameters and by comparing the values of $\mathrm{R}^{2}$ for different length of lags. 
under both specifications. The choice had little effect on results, prompting us to focus on the results based upon the actual $\mathrm{Q}_{\mathrm{t}}{ }^{1{ }^{1}}$

Based on the SZ surplus-share hypothesis, farm share $\hat{\mathrm{m}}$ of the market surplus is negatively related to the quantity (or expected quantity) supplied, and the relationship is specified in the following form:

$$
\hat{\mathrm{m}}_{\mathrm{t}}=\mathrm{e}^{-\alpha \mathrm{Q}_{\mathrm{t}}}, \alpha \geq 0 \text {, and } \hat{\mathrm{m}}_{\mathrm{t}} \in[0,1] .
$$

Substituting (10) and (12) into (6a) and (6b) obtains the following model for estimation:

(6a') $\mathrm{W}_{\mathrm{t}}=\mathrm{c}_{\mathrm{H}}$ for $\mathrm{Q}_{\mathrm{t}} \geq \mathrm{Q}_{\mathrm{H}}$

(6b') $\mathrm{W}_{\mathrm{t}}=\mathrm{c}_{\mathrm{H}}+\mathrm{e}^{-\alpha \mathrm{Q}_{\mathrm{t}}}\left\{\left(\mathrm{E}\left[\mathrm{P}_{\mathrm{t}}\right]-\mathrm{c}_{\mathrm{H}}\right)-\left(\mathrm{A}_{0}+\mathrm{A}_{1} \mathrm{VL}_{\mathrm{t}}\right)-\mathrm{S} \sigma_{\mathrm{P}, \mathrm{t}}\right\}$ for $\mathrm{Q}_{\mathrm{t}}<\mathrm{Q}_{\mathrm{H}}$,

where, from (11), E[ $\left.\mathrm{P}_{\mathrm{t}}\right]=\mathrm{B}_{0}+\mathrm{B}_{1} \mathrm{Q}_{\mathrm{t}}+\mathrm{B}_{2} \mathrm{P}_{\mathrm{t}-1}+\mathrm{B}_{3} \mathrm{P}_{\mathrm{t}-2}+\mathrm{B}_{4} \mathrm{~S}_{\mathrm{t}}+\mathrm{B}_{5} \mathrm{~S} 2_{\mathrm{t}}+\mathrm{B}_{6} \mathrm{~T}_{\mathrm{t}}$, and $\sigma_{\mathrm{P}, \mathrm{t}}$ is specified $\operatorname{via}(9)$.

Equation (6b') can be used for testing the hypotheses about market power and risk aversion. If $\alpha$ is significantly greater than zero, the hypothesis of perfect competition is rejected. Likewise, if the risk aversion coefficient, $\mathrm{S}$, is significantly greater than zero, it provides support for the hypothesis that marketing firms are risk averse.

Given that farm price is determined based upon two distinct pricing regimes depending upon the level of the potential harvest, equations (6a') and (6b') define a switching regression model (SZ, 1996). The switching regression framework was not necessary in the present estimation because the farm price was not constrained by a harvest cost floor during the sample period, as table 1 indicates, in part due to the

\footnotetext{
${ }^{11}$ The forecasting model utilized for $\mathrm{Q}$ was as follows:
} 
government's supply-control program. In other words, given that the harvest-cost pricing regime was not observed during the sample period, estimation could proceed based solely upon (6b'). However, both pricing regimes are relevant to our subsequent evaluation of the supply-control program because in the absence of a supply-control program, the farm price may be constrained by the level of harvest costs.

\section{Data}

The analysis utilized 142 weekly observations from 1996 to 2002. Since only the Taipei market, the largest in Taiwan, has data on both farm price and wholesale price, the model is applied to produce shipped to Taipei. The Council of Agriculture, Taiwan reports daily the farm price, W, and the quantity, Q, shipped to the Taipei Agricultural Product Marketing Company. The company recorded daily the wholesale price, $\mathrm{P}$, up to year 2002. The farm price is the price received at the company by farmers. Farmers hire trucks to haul the produce from the producing regions to the company, where the produce is sold in an ascending-bid auction. The wholesalers trim and repack the product and sell it, usually in open market to retailers and other downstream buyers. The variables $\mathrm{W}, \mathrm{P}$, and Q are all measured in terms of a standard case of Chinese cabbage. The monthly factory wage VL was obtained from Wage and Productivity Statistics Monthly, Taiwan. The same wage was assigned to all weeks within the same month. All monetary values were adjusted by the consumer price index $(1996=100)$.

$\mathrm{Q}_{\mathrm{t}}=\alpha_{0}+\alpha_{1} \mathrm{P}_{\mathrm{t}-1}+\alpha_{2} \mathrm{P}_{\mathrm{t}-2}+\alpha_{3} \mathrm{Q}_{\mathrm{t}-1}+\alpha_{4} \mathrm{Q}_{\mathrm{t}-2}+\alpha_{5} \mathrm{~S} 1_{\mathrm{t}}+\alpha_{6} \mathrm{~S} 2_{\mathrm{t}}+\alpha_{7} \mathrm{~T}_{\mathrm{t}}+\varepsilon_{\mathrm{t}}, \varepsilon_{\mathrm{t}}=\rho \varepsilon_{\mathrm{t}-1}+v_{\mathrm{t}}$, where $v_{\mathrm{t}}$ is white noise. Results from the estimation based upon this specification are available from the authors. 


\section{Results}

Column 3 in table 2 reports the estimated GARCH model. ${ }^{12}$ The estimates for the most part conform to prior expectations. Current period output has a significant negative effect on price, but demand is quite elastic, i.e., the elasticity at the data means is -4.2. Other authors have estimated less elastic demands for produce commodities, but this result seems consistent with the observation that Taiwanese consumers view Chinese cabbage as a close substitute for other leafy vegetables. ${ }^{13}$ The coefficient for S1 confirms the strong effect of Chinese New Year on price, and the coefficient for S2, though not statistically significant, supports the predicted decline in demand after the holiday. However, the estimation provides comparatively little support for the conditional heteroskedastic specification of $\operatorname{var}\left(\mathrm{P}_{\mathrm{t}}\right)$. The coefficient estimates for $\exists_{1}$ and $\exists_{2}$ from (9) are not jointly significant. A Wald test for the hypothesis $\exists_{1}=\exists_{2}=0$ has test statistic $3.17 \chi^{2}$, with a $p$ value of 0.205 .

In estimating (6b'), predicted values, $\hat{\mathrm{P}}_{t}$, from the price equation (11) were used for $\mathrm{E}\left[\mathrm{P}_{\mathrm{t}}\right], \Phi_{\mathrm{P}, \mathrm{t}}=\sqrt{\hat{\sigma}_{\mathrm{P}, \mathrm{t}}^{2}}$ was generated from the GARCH model as specified in (9), and an additive error term was also appended to the equation. The model was estimated by the

\footnotetext{
${ }^{12}$ Our dataset includes observations of seven winter harvest seasons from 1996-2002. Each season starts in October and ends in March of the following year. Thus, the dataset is discontinuous between seasons. In order to solve the discontinuity problem in the GARCH estimation of the price equation, we first constructed one GARCH equation with the same specification for each season. Then we used maximum likelihood estimation to estimate the six GARCH equations jointly by restricting all parameters to be the same across equations. We lost the first two observations of each season due to the two-period lag of price in (8).

${ }^{13}$ During the winter season in Taiwan, consumers can choose from among several leafy vegetables, including, in addition to Chinese cabbage, common cabbage, bok choy, baby bok choy, choy sum, spinach, Chinese broccoli, and mustard greens. In recent years, Chinese cabbage and common cabbage have become relatively close substitutes for hot pot, which is the main use for Chinese cabbage in the winter.
} 
non-linear maximum likelihood method. The estimates converge under alternative starting values.

Estimation results for (6b') are provided in column 3 of table $3 .^{14}$ The overall explanatory power of the model is high, with $\mathrm{R}^{2}=0.863$. For the general model, $\hat{\alpha}>0$ and is strongly statistically significant, supporting the hypothesis that wholesalers exercise market power in procurement. Each of the wholesaling cost coefficients has the predicted positive sign (higher wholesaling costs reduce net surplus), and although neither is individually statistically significant (both have $\mathrm{p}$ values of 0.16 ), they are jointly strongly significant. However, the estimated risk aversion coefficient, $\hat{\mathrm{S}}$, is not statistically significant $(\mathrm{p}$ value $=0.76)$ and, moreover, its sign is negative, consistent with risk-loving behavior rather than risk aversion. One explanation for the failure of the estimation to discern a significant risk effect is that the data set provides limited evidence of variation over time in $\sigma_{\mathrm{P}, \mathrm{t}}$ as the table 2 results demonstrate, thus making it difficult to identify agents' risk behavior. However, it may simply be that price risk for Chinese cabbage has little impact on Taiwanese wholesalers. For example, most market a variety of vegetables, and they may be able to diversify risk through this "portfolio" of products. $^{15}$

The insignificance of $\hat{\mathrm{S}}$ coupled with the weak a priori expectations as to the role of risk in this market suggested that the farm pricing model should be re-estimated without the risk component. These results are reported in column 4 of table 3 . Notably, the

\footnotetext{
${ }^{14}$ Tests of the residuals revealed no evidence of autocorrelation among the error terms in any of the models reported in table 3.

${ }^{15}$ Note that we cannot exclude the possibility that the estimated constant term includes, in addition to the effects of variable inputs whose prices were constant over the short time series, a constant risk premium consistent with the notion that the data provides little evidence of time varying $\operatorname{var}\left(\mathrm{P}_{\mathrm{t}}\right)$.
} 
results for the other coefficients, $\hat{\alpha}, \hat{\mathrm{A}}_{0}$, and $\hat{\mathrm{A}}_{1}$ are robust to this change in model specification, and exclusion of the risk term has almost no effect on the model's explanatory power, as measured by adjusted $\mathrm{R}^{2}$ and the value of the log likelihood function.

Additional analysis of the model's sensitivity to specification is contained in columns 5 and 6 of table 3 . Column 5 eliminates the constant term, $\mathrm{A}_{0}$, from the no-risk model in column 4. The constant term is marginally significant ( $p$ value of 0.08 ) in the model in column 4 of table 3. Its exclusion causes the coefficient on the labor wage to become strongly significant. Elimination of the constant term has almost no effect on the model's overall fit. Finally, Column 6 reports results for the no-risk-aversion model, using E[Q], expected output-see footnote 11, rather than actual output. This alternative specification produced a substantially poorer overall fit relative to the model with actual Q.

The lack of significant coefficients in the variance equation, (9), and the lack of evidence that risk is a significant factor affecting wholesaler behavior suggest that a plausible re-specification of the model is to estimate $\mathrm{P}_{\mathrm{t}}$ in a model with conditional homoskedastic errors and utilize the predicted values from this model to re-estimate the farm pricing equation. Column 4 in table 2 contains estimates for the pricing model with constant conditional variance. Comparison of the column 4 results with the results of the GARCH model in column 3 shows that the estimated coefficients in the wholesale pricing equation are quite robust to the alternative specifications. ${ }^{16}$

\footnotetext{
${ }^{16}$ The price equation with constant conditional variance can also be expressed as $\left(1-\mathrm{B}_{2} \mathrm{~L}-\mathrm{B}_{3} \mathrm{~L}^{2}\right) \mathrm{P}_{t}=\mathrm{B}_{0}+\mathrm{B}_{1} \mathrm{Q}_{\mathrm{t}}+\mathrm{B}_{4} \mathrm{~S} 1+\mathrm{B}_{5} \mathrm{~S} 2+\mathrm{B}_{6} \mathrm{~T}+\varepsilon_{\mathrm{t}}$. Because the roots of the difference equation,
} 
Table 4 contains various formulations of the farm-pricing model based on $\hat{\mathrm{P}}_{\mathrm{t}}$ generated from the pricing model with constant conditional variance. Column 3 reports estimates for the general model, excluding the risk term and, thus, these results are directly comparable to the results in column 4 of table 3 , which utilize $\hat{\mathrm{P}}_{\mathrm{t}}$ generated from the GARCH model. The change in the price-forecasting equation has almost no effect on the parameter estimates or overall fit of the model. ${ }^{17}$ In fact all three coefficients are statistically significant at the 10 percent level or less in this model.

Columns 4 and 5 of table 4 report results for two restricted models. Column 4 restricts the farm-share parameter to be a constant, $\hat{\mathrm{m}}=\hat{\mathrm{m}}^{*}$, rather than the variable farmshare parameter, $\hat{\mathrm{m}}=\mathrm{e}^{-\alpha \mathrm{Q}_{\mathrm{t}}}$, based upon the $\mathrm{SZ}$ hypothesis. This model generates a highly significant farm-share estimate $\hat{\hat{m}}^{*}=0.622$, but the constant farm-share formulation is rejected in favor of the variable farm-share formulation, based upon a likelihood ratio test. Finally, restricting the model to perfect competition $(\hat{m}=1)$ in column 5 dramatically reduces the overall fit of the model, indicating the importance of the imperfect competition formulation. ${ }^{18}$ Further, due to its misspecification, this model exhibits significant first-order autocorrelation and the coefficient on labor's wage has the incorrect sign and is statistically significant.

Fitted values for the farm share of the expected market surplus (i.e., expected wholesale price minus wholesaler marginal costs and per-unit harvest costs) were

$1-\hat{\mathrm{B}}_{2} \mathrm{Z}-\hat{\mathrm{B}}_{3} \mathrm{Z}^{2}=0$, lie outside the unit circle for our estimates, $\hat{\mathrm{B}}_{2}=1.13$ and $\hat{\mathrm{B}}_{3}=-0.34$, we conclude that the second-order difference system of the price equation is stable. We use the same method and find that the system of the price equation with GARCH is also stable.

17 Note that the log likelihood functions are not comparable between tables 3 and 4 because more observations are available for the table 4 models with constant conditional variance. 
computed as $\hat{\hat{m}}_{\mathrm{t}}=\mathrm{e}^{-\hat{\hat{\alpha}} \mathrm{Q}_{\mathrm{t}}}$, where $\hat{\alpha}=1.97 \times 10^{-5}$ is based upon the general model, excluding the risk term, with constant conditional variance (table 4, column 3). The fitted values range from 0.174 to 0.834 , with mean $\overline{\hat{\mathrm{m}}}=0.490$ and standard deviation $\hat{\sigma}_{\hat{\mathrm{m}}}=0.108$. The estimates suggest that, on average, wholesalers are able to capture about half of the market surplus generated from producing and marketing Chinese cabbage, but that the farm share is very sensitive to the volume of product on the market, a result consistent with the SZ hypothesis that farm share of the market surplus power is inversely related to the magnitude of the harvest.

These results regarding buyer market power are consistent with the observed structure of the Taipei market and the format of the auction. Since the inception of the Taipei Agricultural Product Marketing Company 30 years ago, entry has been limited by a licensing requirement, justified nominally based upon quality control and building space limitations. Four types of licenses are issued, but only firms who hold the first three types are able to sell their purchases in the wholesale market. ${ }^{19}$ Holders of the fourth type of license are allowed to make purchases at the market but are not allowed to sell at the market, putting this group of license holders at a competitive disadvantage. No new licenses of the first three types have been issued since the inception of the Company, meaning that the same group of incumbents has been competing together for decades.

Among prototype auction formats, Robinson (1985) showed that ascending (English) style auctions are more susceptible to bidder collusion than are sealed bid or descending (Dutch) auctions. Similarly, auction settings where there is little product differentiation

\footnotetext{
${ }^{18}$ Note that a $\mathrm{t}$ test causes the null hypothesis of perfect competition, $\mathrm{H}_{0}: \hat{\mathrm{m}}=1$, to be rejected at the 0.01 significance level.
} 
and repeated competition among the same group of buyers facilitate the opportunity for coordination among buyers [Porter and Zona (1999), Pesendorfer (2000)].

\section{Application to Taiwan's Chinese Cabbage Supply-Control Program}

To consider the impact of Taiwan's supply-control program, let subscript ' 0 ' denote outcomes in the absence of supply control and subscript ' 1 ' denote outcomes with supply control. Define market price under either regime as

$$
\mathrm{W}_{\mathrm{i}}=\mathrm{c}_{\mathrm{H}}+\max \left\{0, \hat{\mathrm{m}}_{\mathrm{i}}\left(\hat{\mathrm{P}}_{\mathrm{i}}-\mathrm{c}-\mathrm{c}_{\mathrm{H}}\right)\right\}, \mathrm{i}=0,1,{ }^{20}
$$

where $\hat{P}_{i}=E\left[P\left(Q_{i}\right)\right]$ denotes the expected wholesale price, given marketed volume $Q_{i}$. At the time of implementation of a supply-control program, all production costs are sunk costs except for harvest costs, $\mathrm{c}_{\mathrm{H}}$. Thus, producer surplus is

$$
\mathrm{R}_{\mathrm{i}}=\mathrm{Q}_{\mathrm{i}}\left(\mathrm{W}_{\mathrm{i}}-\mathrm{c}_{\mathrm{H}}\right), \mathrm{i}=0,1 \text {. }
$$

The effects of supply control on producer surplus can be derived directly from (13):

(14a) $\Delta \mathrm{R}=0$, for $\mathrm{Q}_{1} \geq \mathrm{Q}_{\mathrm{H}}$,

(14b) $\Delta \mathrm{R}=\hat{\mathrm{m}}_{1}\left(\hat{\mathrm{P}}_{1}-\mathrm{c}-\mathrm{c}_{\mathrm{H}}\right) \mathrm{Q}_{1}$, for $\mathrm{Q}_{0} \geq \mathrm{Q}_{\mathrm{H}}>\mathrm{Q}_{1}$,

(14c) $\Delta \mathrm{R}=\hat{\mathrm{m}}_{1}\left(\hat{\mathrm{P}}_{1}-\mathrm{c}-\mathrm{c}_{\mathrm{H}}\right) \mathrm{Q}_{1}-\hat{\mathrm{m}}_{0}\left(\hat{\mathrm{P}}_{0}-\mathrm{c}-\mathrm{c}_{\mathrm{H}}\right) \mathrm{Q}_{0}$, for $\mathrm{Q}_{0}<\mathrm{Q}_{\mathrm{H}}$.

If $\mathrm{Q}_{0} \geq \mathrm{Q}_{\mathrm{H}}$, producer surplus, $\mathrm{R}_{0}$, is zero, and the increase in producer surplus from supply control is simply the total surplus, if any, generated after the supply controls have been implemented. For the case where $\mathrm{Q}_{0} \geq \mathrm{Q}_{\mathrm{H}}$ define $\hat{\mathrm{m}}_{\mathrm{H}}=\mathrm{e}^{-\alpha \mathrm{Q}_{\mathrm{H}}}$ and $\hat{\mathrm{P}}_{\mathrm{H}}=\mathrm{E}\left[\mathrm{P}\left(\mathrm{Q}_{\mathrm{H}}\right)\right]$, and add and subtract the terms $\hat{\mathrm{m}}_{\mathrm{H}}\left(\hat{\mathrm{P}}_{\mathrm{H}}-\mathrm{c}-\mathrm{c}_{\mathrm{H}}\right) \mathrm{Q}_{1}$ and $\hat{\mathrm{m}}_{\mathrm{H}}\left(\hat{\mathrm{P}}_{1}-\mathrm{c}-\mathrm{c}_{\mathrm{H}}\right) \mathrm{Q}_{1}$ on the right-

\footnotetext{
19 The first three types of licenses are differentiated based upon the size of space allocated to the wholesaler.

${ }^{20}$ The risk-neutral formulation is consistent with the empirical results for this study. In settings where risk aversion was found, the formulation for $\mathrm{W}_{\mathrm{i}}$ would include a risk premium, $\mathrm{S} \Phi_{\mathrm{P}}$.
} 
hand side of (14b). Also add and subtract the terms $\hat{\mathrm{m}}_{0}\left(\hat{\mathrm{P}}_{0}-\mathrm{c}-\mathrm{c}_{\mathrm{H}}\right) \mathrm{Q}_{1}$ and $\hat{\mathrm{m}}_{0}\left(\hat{\mathrm{P}}_{1}-\mathrm{c}-\mathrm{c}_{\mathrm{H}}\right) \mathrm{Q}_{1}$ to the right-hand side of $(14 \mathrm{c})$ to obtain:

(15a) $\Delta \mathrm{R}=0$, for $\mathrm{Q}_{1} \geq \mathrm{Q}_{\mathrm{H}}$,

(15b) $\Delta \mathrm{R}=\left(\hat{\mathrm{m}}_{1}-\hat{\mathrm{m}}_{\mathrm{H}}\right)\left(\hat{\mathrm{P}}_{1}-\mathrm{c}-\mathrm{c}_{\mathrm{H}}\right) \mathrm{Q}_{1}+\left(\hat{\mathrm{P}}_{1}-\hat{\mathrm{P}}_{\mathrm{H}}\right) \mathrm{Q}_{1} \hat{\mathrm{m}}_{\mathrm{H}}$, for $\mathrm{Q}_{0} \geq \mathrm{Q}_{\mathrm{H}}>\mathrm{Q}_{1}$,

(15c) $\Delta \mathrm{R}=\left(\hat{\mathrm{m}}_{1}-\hat{\mathrm{m}}_{0}\right)\left(\hat{\mathrm{P}}_{1}-\mathrm{c}-\mathrm{c}_{\mathrm{H}}\right) \mathrm{Q}_{1}+\left(\hat{\mathrm{P}}_{1}-\hat{\mathrm{P}}_{0}\right) \mathrm{Q}_{1} \hat{\mathrm{m}}_{0}-\left(\mathrm{Q}_{0}-\mathrm{Q}_{1}\right) \hat{\mathrm{m}}_{0}\left(\hat{\mathrm{P}}_{0}-\mathrm{c}-\mathrm{c}_{\mathrm{H}}\right)$, for $\mathrm{Q}_{0}<\mathrm{Q}_{\mathrm{H}}$.

Alternatively, the expressions for $\Delta \mathrm{R}$ can be written directly in terms of the farm price, $\mathrm{W}$, as follows:

(16a) $\Delta \mathrm{R}=0$, for $\mathrm{Q}_{1} \geq \mathrm{Q}_{\mathrm{H}}$,

(16b) $\Delta \mathrm{R}=\mathrm{Q}_{1}\left(\mathrm{~W}_{1}-\mathrm{c}_{\mathrm{H}}\right)\left(1-\frac{\hat{\mathrm{m}}_{\mathrm{H}}}{\hat{\mathrm{m}}_{1}}\right)+\mathrm{Q}_{1}\left(\mathrm{~W}_{1}-\mathrm{c}_{\mathrm{H}}\right)\left(\frac{\hat{\mathrm{m}}_{\mathrm{H}}}{\hat{\mathrm{m}}_{1}}\right)$, for $\mathrm{Q}_{0} \geq \mathrm{Q}_{\mathrm{H}}>\mathrm{Q}_{1}$,

(16c) $) \mathrm{R}=\mathrm{Q}_{1}\left(\mathrm{~W}_{1}-\mathrm{c}_{\mathrm{H}}\right)\left(1-\frac{\hat{\mathrm{m}}_{0}}{\hat{\mathrm{m}}_{1}}\right)+\mathrm{Q}_{1}\left[\left(\mathrm{~W}_{1}-\mathrm{c}_{\mathrm{H}}\right) \frac{\hat{\mathrm{m}}_{0}}{\hat{\mathrm{m}}_{1}}-\left(\mathrm{W}_{0}-\mathrm{c}_{\mathrm{H}}\right)\right]-\left(\mathrm{Q}_{0}-\mathrm{Q}_{1}\right)\left(\mathrm{W}_{0}-\mathrm{c}_{\mathrm{H}}\right)$, for $\mathrm{Q}_{0}<\mathrm{Q}_{\mathrm{H}}$.

When $\mathrm{Q}_{0}<\mathrm{Q}_{\mathrm{H}}$, the surplus change in either (15) or (16) consists of three terms. The first term, the "share effect," is the revenue effect due to a larger producer share $\left(\hat{\mathrm{m}}_{1}-\hat{\mathrm{m}}_{0}\right)$ caused by reduced sales. The second term is the "price effect"--the producer revenue, given producer share $\hat{\mathrm{m}}_{0}$, of the higher wholesale price $\left(\hat{\mathrm{P}}_{1}-\hat{\mathrm{P}}_{0}\right)$ from reduced sales, caused by movement along the expected demand curve. The third term, the "output effect" is the effect on revenues from reduced sales $\left(\mathrm{Q}_{0}-\mathrm{Q}_{1}\right)$, given wholesale price and producer share. In (15b) or (16b) $\Delta \mathrm{R}$ consists of only two terms because the output effect is zero when $\mathrm{Q}_{0}>\mathrm{Q}_{\mathrm{H}}$.

The second and third effects represent the usual result from deriving marginal revenue in the presence of a downward sloping demand. In the absence of buyer market power considerations, these effects would determine when supply control was surplus 
enhancing to producers, namely when farm-level marginal revenue evaluated at $\mathrm{Q}_{0}$ was less than per-unit harvest costs, $\mathrm{c}_{\mathrm{H}}$. Expressing this condition in terms of the wholesale market price elasticity of demand, $\varepsilon_{Q, \mathrm{w}}$, generates the following condition:

$\frac{\mathrm{W}_{0}-\mathrm{c}_{\mathrm{H}}}{\mathrm{W}_{0}}<\frac{1}{\left|\varepsilon_{\mathrm{Q}_{0}, \mathrm{~W}_{0}}\right|}=\left|\mathrm{F}_{\mathrm{W}_{0}, \mathrm{Q}_{0}}\right|$,

where $\mathrm{F}_{\mathrm{w}_{0}, \mathrm{Q}_{0}}$ is the price flexibility of wholesale demand evaluated at $\left(\mathrm{W}_{0}, \mathrm{Q}_{0}\right)$.

Whenever $\hat{\mathrm{m}}<1$, the farm price is less flexible in response to a decrease in quantity than under perfect competition because marketers capture part of the price increase caused by reduced quantity. Thus, in the absence of any effect of reduced sales on producer share of the market surplus, supply-control programs are less likely to benefit producers in the presence of market power because the exercise of market power makes the farm price less flexible and, hence, less responsive to the reduction in supply caused by a supplycontrol program.

To utilize (16) to evaluate the benefits to Chinese cabbage producers from government crop removal during the 1996-2002 crop years, note that $\mathrm{Q}_{0}, \mathrm{Q}_{1}$, and $\mathrm{W}_{1}$ are known. We first solved (6b') for $\mathrm{Q}_{\mathrm{H}}$ by setting $\mathrm{W}_{\mathrm{t}}=\mathrm{c}_{\mathrm{H}}$, other variables being constant. Farm shares $\hat{\mathrm{m}}_{0}, \hat{\mathrm{m}}_{1}$, and $\hat{\mathrm{m}}_{\mathrm{H}}$ were estimated using (12), and $\mathrm{W}_{0}$ was estimated using (6b'). All estimates rely upon results from the general model without risk effects- table 4, column 3. The overall evaluation of the supply-control program is contained in table 1, and table 5 decomposes the overall effect into its three components. ${ }^{21}$ Because the empirical model was estimated using the price and quantity data for the Taipei market, evaluation of the supply-control program focuses on the Taipei market. In table 1, the 
value of $\mathrm{Q}_{0}$ in any week $\mathrm{t}$ is the Taipei weekly sales volume $\mathrm{Q}_{1}$ plus Taipei's market share times the total volume of produce withdrawn from all of Taiwan for that week under the policy. In other words, $\mathrm{Q}_{0}$ is the actual sales plus Taipei's share of any supply reduction due to supply control. During the study period, Taipei's average weekly market share was $45 \%$.

A striking result from table 1 is that, in the absence of implementation of the supplycontrol program, it is predicted that the farm price would have fallen to the immutable floor set by the level of per-unit harvest costs in most of the periods when supply control was implemented. In those periods, $\mathrm{Q}_{0} \geq \mathrm{Q}_{\mathrm{H}}$. Only for the periods of supply control implemented in 1997-98 and in Dec. 17-30, 2001 is it estimated that $\mathrm{W}_{0}>60$. In all instances except the 1997-98 supply controls, the farm price after implementation of the policy remained well below the estimated full cost of production of about NT\$150 per std. case. $^{22}$

Consider now the decomposition of the total change in producer surplus contained in table 5. The output effect is zero except for the 1997-98 and December 17-30, 2001 periods when $\mathrm{Q}_{0}<\mathrm{Q}_{\mathrm{H}}$. Accordingly, during these periods the opportunity cost of plowing crop under instead of harvesting it was zero. The output effect was large, however, for the 1997-98 supply controls, and is estimated to have reduced net benefits from the program for that period by NT $\$ 708.35$ thousand.

\footnotetext{
${ }^{21}$ There are 7 crop years in the study period. However, there was no government intervention in 19992000.

${ }^{22}$ In considering this result, note that the supply controls are applied in periods of low, below-cost prices. Thus, even though producers were still losing money during the periods of supply control, they may have earned profits when returns are evaluated over a longer time horizon, such as one or more seasons. Longrun profitability was not addressed in this study.
} 
The share effect and the price effect each comprised substantial shares of program benefits for most of the weekly episodes of supply control. Of a total estimated benefit to producers of NT $\$ 8,705,299$ from supply control during the sample period, NT $\$ 2,592,523$ (29.8\%) is estimated to have been due to an improved producer surplus share, as a consequence of reduced supplies on the market. The benefit from the price effect is estimated to have been NT\$7,132,544 (81.9\%), with -NT\$1,019,769 (-11.7\%) estimated to have been due to the output effect.

A measure of the efficiency of the supply-control policy is the increase generated in producer surplus per standard case of crop withdrawn. From table 1, columns 2 and 5, this measure varies from a low of about NT $\$ 10.7$ for the supply control implemented in Jan. 25-31, 1999 to a high of NT\$64 for the Dec. 8-14, 1997 supply control. Notably, the periods of highest policy efficiency occurred when supply control was applied to markets where price was already relatively high prior to implementation of supply controls, i.e., the 1997-98 supply controls and the December 17-30, 2001 supply controls. In these situations, farmers were able to capture a relatively high share of the program benefits. Even though supply controls enable producers to capture a higher share of the market surplus, the share is low nonetheless when supplies are large and price is near the harvest-cost minimum, meaning that supply controls generate relatively little producer benefit per standard case removed. Thus, we reach the relatively discouraging conclusion that, in the presence of wholesaler market power with variable producer shares, supply controls are least effective when they are most needed and most likely to be implemented. 
The supply-control program is implemented through subsidies to producers to remove part of their crops during the harvest seasons (table 1, column 6). The subsidy is intended as compensation for the production costs for the crops plowed under. Those years of higher benefit per unit of product withdrawn also show higher benefit per tax dollar spent, based on the constant subsidy per unit of product withdrawn. Notably, in 1995-96 and 1998-99 the program is estimated to have returned less in net benefits to producers than the subsidy cost to the government to implement the program. If market supplies could be forecast accurately, a more efficient program would pay producers to not plant the crop, thereby avoiding the production costs incurred in a plow-under program.

\section{Conclusions}

Extending prior work by Schroeter and Azzam (1991) and Sexton and Zhang (1996), this study has developed a model of price determination where marketing firms' market power and risk behavior can be measured and tested. Traditional risk studies attribute the entire amount of the cost-adjusted farm-wholesale price spread to a risk premium, while in other studies the same price spread is attributed to marketing firm oligopoly and/or oligopsony behavior.

The general model was refined to accommodate the unique market characteristics for a perishable commodity and applied to the market for Chinese cabbage in Taiwan. The empirical results provided strong support for the hypothesis that wholesalers exercised oligopsony power in procuring the product from producers, but there was little evidence that price risk played an important role. 
Fresh produce in many countries is subject to periodic oversupply and wide price fluctuations. Thus public intervention to stabilize and raise producer prices through supply controls may be an attractive option. Our evaluation of the supply-control program for Chinese cabbage in Taiwan indicates that each of the supply-control episodes yielded net benefits to producers. However, the impacts of supply control in these settings can be understood fully only in the context of a model that accounts for the unique features of fresh produce markets and the nature of competition in them. In the present application, it was estimated that the farm price in the absence of supply controls would often have fallen to the immutable floor set by the level of per-unit harvest costs. Thus, the "output effect", the producer surplus lost from destroying otherwise saleable product, was zero in these periods, effectively insuring that the supply controls would yield net benefits to producers.

The presence of oligopsony power introduces an additional benefit to supply control that is not present under perfect competition, namely the opportunity to increase producers' share of the market surplus (i.e., reduce the extent of wholesaler oligopsony power) by having less product available for sale on the market. This "share effect" was estimated to have contributed about 30 percent of the net benefits to producers of Chinese cabbage in Taiwan over the seven-year period evaluated in this study. In this regard, this paper provides new evidence and a new context, government supply controls, to support the general proposition that analyses of the impacts of agricultural policies are sensitive to the form of competition specified in the model of the market, and, therefore, that 
investigation of competition in the market is an important precursor to conducting policy analysis. ${ }^{23}$

\footnotetext{
${ }^{23}$ For additional applications of this general proposition, see the work by Alston, Sexton, and Zhang (1997) and Hamilton and Sunding (1998) on the magnitude and distribution of benefits from agricultural research under alternative competition scenarios, Suzuki et al. (1993) on the impact of fluid milk price supports in a competitive vs. imperfectly competitive market, and Lanclos and Hertel (1995) and McCorriston and Sheldon (1996) on the evaluation of trade barriers under alternative forms of market competition.
} 
Table 1: Price and Producer Surplus Changes for Chinese Cabbage Supply Control, Taipei, 1996-2002

\begin{tabular}{|c|c|c|c|c|c|}
\hline $\begin{array}{l}\text { Dates of } \\
\text { crop removal }\end{array}$ & 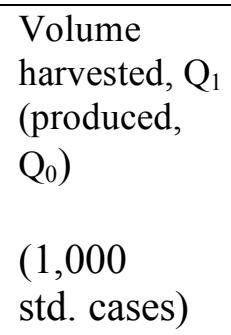 & $\begin{array}{l}\text { Farm } \\
\text { price, } W_{1} \\
\text { (NT\$/ } \\
\text { std. case) }\end{array}$ & $\begin{array}{l}\text { Farm price } \\
\text { without } \\
\text { policy, } \mathrm{W}_{0} \\
\text { (NT\$/ } \\
\text { std. case) }\end{array}$ & $\begin{array}{l}\text { Surplus } \\
\text { change due } \\
\text { to policy, } \\
\Delta \mathrm{R}_{\mathrm{t}} \\
(\mathrm{NT} \$ 1,000)\end{array}$ & $\begin{array}{l}\text { Subsidy for } \\
\text { crop removal }^{\mathrm{a}}\end{array}$ \\
\hline $\begin{array}{l}\text { 1995-96 } \\
\text { Jan. } 15-21 \\
\text { Jan. 22-28 } \\
\text { Jan. 29-Feb. } 4\end{array}$ & $\begin{array}{l}31.7(51.1) \\
40.8(60.2) \\
49.1(68.5) \\
\end{array}$ & $\begin{array}{l}82 \\
81 \\
70 \\
\end{array}$ & $\begin{array}{l}60 \\
60 \\
60 \\
\end{array}$ & $\begin{array}{r}2,045.28 \\
697.40 \\
856.74 \\
491.14 \\
\end{array}$ & $2,485.25$ \\
\hline $\begin{array}{l}\text { 1996-97 } \\
\text { Jan. 20-26 } \\
\text { Jan. 27-Feb.2 }\end{array}$ & $\begin{array}{l}40.7(57.5) \\
53.9(70.7) \\
\end{array}$ & $\begin{array}{l}70 \\
79 \\
\end{array}$ & $\begin{array}{l}60 \\
60 \\
\end{array}$ & $\begin{array}{r}1,430.53 \\
407.11 \\
1,023.42 \\
\end{array}$ & $1,286.91$ \\
\hline $\begin{array}{l}\mathbf{1 9 9 7 - 9 8} \\
\text { Dec. } 1-7 \\
\text { Dec. } 8-14 \\
\text { Dec. } 15-21 \\
\text { Dec. } 22-28 \\
\end{array}$ & $\begin{array}{l}40.4(43.2) \\
47.4(50.2) \\
39.2(42.0) \\
39.6(42.4)\end{array}$ & $\begin{array}{l}102 \\
148 \\
142 \\
133 \\
\end{array}$ & $\begin{array}{r}95.4 \\
139.5 \\
133.2 \\
124.7 \\
\end{array}$ & $\begin{array}{l}632.58 \\
165.88 \\
179.11 \\
140.27 \\
147.32 \\
\end{array}$ & 456.14 \\
\hline $\begin{array}{l}\mathbf{1 9 9 8 - 9 9} \\
\text { Jan. 18-24 } \\
\text { Jan. } 25-31 \\
\text { Feb. } 1-7 \\
\end{array}$ & $\begin{array}{l}46.5(69.6) \\
41.3(64.4) \\
39.8(62.9)\end{array}$ & $\begin{array}{l}73 \\
66 \\
82 \\
\end{array}$ & $\begin{array}{l}60 \\
60 \\
60 \\
\end{array}$ & $\begin{array}{r}1,728.39 \\
605.14 \\
247.89 \\
875.36 \\
\end{array}$ & $2,488.53$ \\
\hline $\begin{array}{l}\text { 2000-01 } \\
\text { Feb. 5-11 }\end{array}$ & $32.8(66.5)$ & 97 & 60 & $1,215.38$ & $1,134.08$ \\
\hline $\begin{array}{l}\text { 2001-02 } \\
\text { Dec. } 10-16 \\
\text { Dec. } 17-23 \\
\text { Dec. } 24-30 \\
\end{array}$ & $\begin{array}{l}42.8(53.7) \\
34.5(45.3) \\
32.4(43.3) \\
\end{array}$ & $\begin{array}{r}69 \\
88 \\
108 \\
\end{array}$ & $\begin{array}{c}60 \\
66.6 \\
82.1 \\
\end{array}$ & $\begin{array}{r}1,653.15 \\
385.42 \\
666.65 \\
601.08 \\
\end{array}$ & $1,237.30$ \\
\hline
\end{tabular}


Table 2: Estimation Results for the GARCH Model and the Wholesale Pricing Model with Constant Conditional Variance

\begin{tabular}{|c|c|c|c|}
\hline $\begin{array}{l}\text { Parameter } \\
\text { (1) }\end{array}$ & $\begin{array}{l}\text { Variable } \\
\text { (2) }\end{array}$ & $\begin{array}{c}\text { GARCH model } \\
\text { (3) }\end{array}$ & $\begin{array}{l}\text { Constant conditional } \\
\text { variance model } \\
\text { (4) }\end{array}$ \\
\hline $\mathrm{B}_{0}$ & Constant & $\begin{array}{l}223.85 \\
(2.25)^{*}\end{array}$ & $\begin{array}{l}253.78 \\
(3.98)^{*}\end{array}$ \\
\hline $\mathrm{B}_{1}$ & $\mathrm{Q}_{\mathrm{t}}$ & $\begin{array}{l}-0.0030 \\
(2.03)^{*}\end{array}$ & $\begin{array}{l}-0.0036 \\
(3.43)^{*}\end{array}$ \\
\hline $\mathrm{B}_{2}$ & $P_{t-1}$ & $\begin{array}{l}1.19 \\
(9.89)^{*}\end{array}$ & $\begin{array}{c}1.13 \\
(15.03)^{*}\end{array}$ \\
\hline $\mathrm{B}_{3}$ & $P_{t-2}$ & $\begin{array}{l}-0.39 \\
(3.82)^{*}\end{array}$ & $\begin{array}{l}-0.34 \\
(4.99)^{*}\end{array}$ \\
\hline $\mathrm{B}_{4}$ & S1 & $\begin{array}{l}148.48 \\
(1.79)^{*}\end{array}$ & $\begin{array}{l}178.1 \\
(3.42)^{*}\end{array}$ \\
\hline $\mathrm{B}_{5}$ & S2 & $\begin{array}{r}-61.22 \\
(1.46)\end{array}$ & $\begin{array}{l}-51.1 \\
(1.39)\end{array}$ \\
\hline $\mathrm{B}_{6}$ & $\mathrm{~T}$ & $\begin{array}{l}-2.99 \\
(1.18)\end{array}$ & $\begin{array}{l}-2.95 \\
(1.85)^{*}\end{array}$ \\
\hline$\exists_{0}$ & Constant & $\begin{array}{l}5,008.76 \\
\quad(4.83)^{*}\end{array}$ & \\
\hline$\exists_{1}$ & $\mu_{t-1}^{2}$ & 0.195 & \\
\hline$\exists_{2}$ & $Z_{t-1}$ & $\begin{array}{r}(1.18) \\
0.103 \\
(0.51)\end{array}$ & \\
\hline $\mathrm{R}^{2}$ & & & 0.87 \\
\hline Log likelihood & & -698.91 & -745.47 \\
\hline
\end{tabular}

Notes: Absolute t statistics are in parentheses.

* denotes statistical significance at the $10 \%$ level or less. 
Table 3: The Farm Pricing Model-Various Specifications

\begin{tabular}{|c|c|c|c|c|c|}
\hline $\begin{array}{l}\text { Parameter } \\
\text { (1) }\end{array}$ & $\begin{array}{l}\text { Variable } \\
\text { (2) }\end{array}$ & $\begin{array}{c}\text { General model } \\
\text { equation (6b') } \\
\text { (3) }\end{array}$ & $\begin{array}{c}\text { Model } 2 \\
\text { (general model, } \\
\text { no risk term) } \\
(4)\end{array}$ & $\begin{array}{c}\text { Model } 3 \\
\text { (model } 2 \text { exc. } \\
\text { constant) } \\
(5)\end{array}$ & $\begin{array}{c}\text { Model } 4 \\
\text { (model } 2 \text { with } \\
\text { E[Q]) } \\
(6)\end{array}$ \\
\hline$\forall$ & $\mathrm{e}^{-\alpha \mathrm{Q}}$ & $\begin{array}{c}2.06 \times 10^{-5} \\
(10.26)^{*}\end{array}$ & $\begin{array}{l}2.04 \times 10^{-5} \\
(11.00)^{*}\end{array}$ & $\begin{array}{c}2.29 \times 10^{-5} \\
(18.49)^{*}\end{array}$ & $\begin{array}{c}1.61 \times 10^{-5} \\
(9.50)^{*}\end{array}$ \\
\hline $\mathrm{A}_{0}$ & Constant & $\begin{array}{r}99.425 \\
(1.40)\end{array}$ & $\begin{array}{l}82.870 \\
(1.80)^{*}\end{array}$ & & $\begin{array}{l}134.14 \\
(3.11)^{*}\end{array}$ \\
\hline $\mathrm{A}_{1}$ & VL & $\begin{array}{l}0.224 \\
(1.39)\end{array}$ & $\begin{array}{l}0.222 \\
(1.40)\end{array}$ & $\begin{array}{l}0.487 \\
(7.69)^{*}\end{array}$ & $\begin{array}{l}0.106 \\
(0.69)\end{array}$ \\
\hline S & $\Phi_{\mathrm{P}}$ & $\begin{array}{l}-0.223 \\
(0.31)\end{array}$ & & & \\
\hline Adj. $R^{2}$ & & 0.863 & 0.864 & 0.862 & 0.819 \\
\hline $\begin{array}{l}\text { Log } \\
\text { likelihood } \\
\text { function }\end{array}$ & & -647.84 & -647.89 & -649.17 & -665.12 \\
\hline
\end{tabular}

Notes: All models use $\hat{\mathrm{P}}_{\mathrm{t}}$ from the GARCH model.

Absolute $t$ statistics are in parentheses.

* denotes statistical significance at the $10 \%$ level or less. 
Table 4: The Farm Pricing Model--Various Competition Scenarios

\begin{tabular}{|c|c|c|c|c|}
\hline $\begin{array}{l}\text { Parameter } \\
\text { (1) }\end{array}$ & $\begin{array}{l}\text { Variable } \\
\text { (2) }\end{array}$ & $\begin{array}{l}\text { General model, } \\
\text { no risk term } \\
\text { (3) }\end{array}$ & $\begin{array}{l}\text { Constant surplus } \\
\text { share model } \\
\text { (4) }\end{array}$ & $\begin{array}{c}\text { Perfect } \\
\text { competition } \\
\text { model }(\hat{\mathrm{m}}=1) \\
(5)\end{array}$ \\
\hline$\hat{\mathrm{m}}^{*}$ & & & $\begin{array}{c}0.622 \\
(22.23)^{*}\end{array}$ & \\
\hline$\forall$ & $\mathrm{e}^{-\alpha Q}$ & $\begin{array}{l}1.97 \times 10^{-5} \\
(11.12)^{*}\end{array}$ & & \\
\hline $\mathrm{A}_{0}$ & Constant & $\begin{array}{l}91.683 \\
(2.15)^{*}\end{array}$ & $\begin{array}{l}169.727 \\
(5.19)^{*}\end{array}$ & $\begin{array}{l}310.822 \\
(10.03)^{*}\end{array}$ \\
\hline $\mathrm{A}_{1}$ & VL & $\begin{array}{c}0.254 \\
(1.74)^{*}\end{array}$ & $\begin{array}{l}0.044 \\
(0.37)\end{array}$ & $\begin{array}{l}-0.285 \\
(2.26)^{*}\end{array}$ \\
\hline$\Delta_{1}$ & $\begin{array}{l}\text { Auto- } \\
\text { correlation } \\
\text { parameter }\end{array}$ & & & $\begin{array}{c}0.289 \\
(3.43)^{*}\end{array}$ \\
\hline Adj $R^{2}$ & & 0.863 & 0.826 & 0.621 \\
\hline $\begin{array}{l}\text { Log } \\
\text { likelihood } \\
\text { function }\end{array}$ & & -689.91 & -704.94 & -711.55 \\
\hline
\end{tabular}

Notes: All models utilize $\hat{\mathrm{P}}_{\mathrm{t}}$ from the forecasting model with constant conditional variance. Absolute $\mathrm{t}$ statistics are in parentheses.

* denotes statistical significance at the $10 \%$ level or less. 
Table 5: Decomposition of the Surplus Change for Chinese Cabbage Supply Control, Taipei, 1996-2002

\begin{tabular}{|c|c|c|c|c|}
\hline $\begin{array}{l}\text { Dates of } \\
\text { crop removal }\end{array}$ & Share effect & Price effect & Output effect & $\begin{array}{l}\text { Total surplus } \\
\text { change }\end{array}$ \\
\hline & \multicolumn{4}{|c|}{ (NT\$ 1,000$)$} \\
\hline 1995-96 & & & & $2,045.28$ \\
\hline Jan. 15-21 & 140.40 & 557.00 & 0 & 697.40 \\
\hline Jan. 22-28 & 193.97 & 662.77 & 0 & 856.74 \\
\hline Jan. 29-Feb.4 & 65.87 & 425.27 & 0 & 491.14 \\
\hline 1996-97 & & & & $1,430.53$ \\
\hline Jan. 20-26 & 46.77 & 360.34 & 0 & 407.11 \\
\hline Jan. 27-Feb. 2 & 265.58 & 757.83 & 0 & $1,023.42$ \\
\hline 1997-98 & & & & 632.58 \\
\hline Dec.1-7 & 91.18 & 173.98 & -99.28 & 165.88 \\
\hline Dec. 8-14 & 224.08 & 177.81 & -222.78 & 179.11 \\
\hline Dec. $15-21$ & 172.49 & 172.80 & -205.02 & 140.27 \\
\hline Dec. $22-28$ & 155.35 & 173.25 & -181.27 & 147.32 \\
\hline 1998-99 & & & & $1,728.39$ \\
\hline Jan. $18-24$ & 98.66 & 506.48 & 0 & 605.14 \\
\hline Jan. 25-31 & 17.70 & 230.19 & 0 & 247.89 \\
\hline Feb. 1-7 & 202.86 & 672.50 & 0 & 875.36 \\
\hline $2000-01$ & & & & \\
\hline Feb. 5-11 & 389.80 & 825.58 & 0 & $1,215.38$ \\
\hline 2001-02 & & & & $1,653.15$ \\
\hline Dec. $10-16$ & 41.70 & 343.72 & 0 & 385.42 \\
\hline Dec. $17-23$ & 185.99 & 552.15 & -71.49 & 666.65 \\
\hline Dec. $24-30$ & 300.13 & 540.88 & -239.93 & 601.08 \\
\hline Sample total & $2,592.52$ & $7,132.54$ & $-1,019.77$ & $8,705.30$ \\
\hline
\end{tabular}




\section{References}

Alston, J.M., R.J. Sexton, and M. Zhang. "The Effects of Imperfect Competition on the Size and Distribution of Research Benefits." Amer. J. Agr. Econ. 79(1997): 1252-65.

Aradhyula, S. V., and M. T. Holt. "Risk Behavior and Rational Expectations in the U.S. Broiler Market.” Amer. J. Agr. Econ. 71(1989): 892-902.

Azzam, A. "Market Transparency and Market Structure: The Livestock Mandatory Reporting Act of 1999." Amer. J. Agr. Econ 85(2003): 387-95.

Bar-Shira, $Z$ and I. Finkelshtain. "Two-Moments Decision Models and UtilityRepresentable Preferences.” J.Econ. Behavior \& Org. 38(1999): 237-244.

Brorsen, B. W., J.-P. Chavas, and W. Grant. "A market Equilibrium Analysis of the Impact of Risk on the U.S. Rice Industry.” Amer. J. Agr. Econ. 69(1987): 731-39.

Brorsen, B. W., J.-P. Chavas, W. Grant, and L. D. Schnake. "Marketing Margins and Price Uncertainty: the Case of the U.S. Wheat Market." Amer. J. Agr. Econ. 67(August 1985): 521-28.

Council of Agriculture, Taiwan. "Reports on Taiwan's Agricultural Products' Production Costs," various issues.

Hamilton, S.F. and D.L. Sunding. "Returns to Product Innovation in Agriculture with Imperfect Downstream Competition.” Amer. J. Agr. Econ. 80(1998): 830-38.

Holt, M. T. "Risk Response in the Beef Marketing Channel: A Multivariate Generalized ARCH-M Approach.” Amer. J. Agr. Econ. 75(1993): 559-71.

Hsu, W-F. "The Current Situations and Problems of Vegetable Marketing in Taiwan." Quart. J. Agric. Mtg. (in Chinese) 25(1975): 4-9.

Hsu, W-F. "Research on Marketing Margins and Costs for Major Vegetables in Taiwan." (in Chinese) National Taiwan University, Taipai, Taiwan, 1985.

Hsueh, L., and C-H. Chang. "Research on the Reasonability of Fruit and Vegetable Marketing Margins and Farm Shares in Taiwan." Quart. J. Agric. Mtg. (in Chinese) 84(1990): 9-29.

Huang, C-J. and Y-H. Huang. "Research on the Reasonability of Marketing Margins for Major Vegetables in Taiwan." Quart. J. Agric. Mtg. (in Chinese) 98(1994): 21-36.

Huang, S. Y., and R. J. Sexton. "Measuring Returns to an Innovation in an Imperfectly Competitive Market: Application to Mechanical Harvesting of Processing Tomatoes in Taiwan." Amer. J. Agr. Econ. (1996): 558-71. 
Lanclos, D.K. and T.W. Hertel. "Endogenous Product Differentiation and Trade Policy: Implications for the U.S. Food Industry.” Amer. J. Agr. Econ. 77(1995): 591-601.

Leathers, H.D. and J.C. Quiggin. "Interactions between Agricultural and Resource Policy: The Importance of Attitudes toward Risk." Amer. J. Agr. Econ. (1991): 757764.

Lee, C-M. "Fruit and Vegetable Marketing Margins and Farm Shares in Taiwan." Quart. J. Agric. Mtg. (in Chinese) 78(1989): 17-21.

McCorriston, S. and I.M. Sheldon. "Incorporating Industrial Organization into Trade Models," in D. Martimort, ed., Agricultural Markets: Mechanisms, Failures and Regulations, Amsterdam: North Holland, 313-30.

Meyer, J. "Two-Moment Decision Models and Expected Utility Maximization." Amer. Econ. Rev. 77(1987): 421-430.

Muth, M. and M. Wohlgenant. "Measuring the Degree of Oligopsony Power in the Beef Packing Industry in the Absence of Marketing Input Quantity Data." J. Agr. \& Res. Econ. 24(1999): 299-312.

Ormiston, M.B. and J. Quiggin. "Two-Parameter Decision Models and Rank-Dependent Expected Utility." Journal of Risk and Uncertainty 7(1993): 273-82.

Pesendorfer, M. "A Study of Collusion in First-Price Auctions." Rev. Econ. Stud. 67(2000): 381-411.

Porter, R.H. and J.D. Zona. "Ohio School Milk Markets: An Analysis of Bidding." Rand J. Econ. 30(1999): 263-88.

Richard, T.J. and P.M. Patterson. "Imperfect Competition in Fresh Produce Markets: An Empirical Analysis of Channel Performance." U.S. Department of Agriculture, Economic Research Service, Contractors and Cooperators Report No. 1, Sept. 2003.

Richards, T.J., P.M. Patterson, and R.N. Acharya. "Price Behavior in a Dynamic Oligopsony: Washington Processing Potatoes.” Amer. J. Agr. Econ. 83(May 2001): 259-71.

Rogers, R.T. and R.J. Sexton. "Assessing the Importance of Oligopsony Power in Agricultural Markets.” Amer. J. Agr. Econ.76 (1994): 1143-50.

Robinson, M.S. “Collusion and the Choice of Auction.” Rand J. Econ. 16(1985): 141-45.

Schroeter J., and A. Azzam. "Marketing Margins, Market Power and Price Uncertainty." Amer. J. Agr. Econ. 73(1991): 990-99. 
Sexton, R. J., and M. Zhang. "A Model of Price Determination for Fresh Produce with Application to California Iceberg Lettuce." Amer. J. Agr. Econ. 78(1996): 924-34.

Sexton, R.J. and N. Lavoie. "Food Processing and Distribution: An Industrial Organization Approach." in B. Gardner and G. Rausser (eds.) Handbook of Agricultural Economics, Amsterdam: North Holland, 2001, pp. 863-932.

Sexton, R.J., M. Zhang, and J.A. Chalfant. "Grocery Retailer Behavior in the Procurement and Sale of Perishable Produce Commodities," U.S. Department of Agriculture, Economic Research Service, Contractors and Cooperators Report No. 2, Sept. 2003.

Sinn, H-W. Economic Decisions Under Uncertainty, Amsterdam: North Holland, 1983.

Suzuki, N., J.E. Lenz and O.D. Forker. "A Conjectural Variation Model of Reduced Japanese Milk Price Supports.” Amer. J. Agr. Econ. 75(1993): 210-18.

Taylor, T.G. and R.L. Kilmer. "An Analysis of Market Structure and Pricing in the Florida Celery Industry.” Southern J. Agric. Econ. 20(1988): 35-43. 